\title{
Cirebon Puppets through the Sendratari Show from the Role, Category, Meaning, and Character Values of Pantura Region III West Java's People and Application of the Results for Arts Literature Learning in Senior High School
}

\section{Taiman $^{1}$ and Iskandarwassid ${ }^{2}$}

${ }^{1}$ Indonesian Education Study Program, Indonesian University of Education, Jalan Setiabudhi No.229, Bandung 40154, West Java, Indonesia

${ }^{2}$ Indonesian University of Education, Jalan Setiabudhi No.229, Bandung 40154, West Java, Indonesia

\section{Abstract}

Corresponding Author:

Taiman

taiman_tea@yahoo.com

Received: 6 April 2018

Accepted: 3 May 2018

Published: 26 July 2018

Publishing services provided by Knowledge E

(c) Taiman and

Iskandarwassid. This article is distributed under the terms of

the Creative Commons

Attribution License, which

permits unrestricted use and

redistribution provided that the original author and source are credited.

Selection and Peer-review under the responsibility of the ISLLE 2017 Conference Committee.
The purpose of this study was to know how much Cirebon's applying the cultural values of Cirebon Puppet into daily life. This study uses qualitative approach to illustrate and describe the puppet show. The researchers collect the informations and analyze the data in form of phenomena, thoughts, and perceptions about Cirebon Puppets. The results showed that the character values of Cirebon Puppet's show can be used as arts literature learning in senior high school.

Keywords: character building, Cirebon Puppet, local wisdom

\section{Introduction}

Puppet are a medium of propagation that conveys information through the media. Wayang in the days of the guardians is used as a propagation tool to convey to his people.

Puppetry is one of the original skills of the Indonesian nation, and a wayang performance is an expression and demonstration of religious experience that encapsulates various symbolic elements such as language, motion, dance, sound, literature, color, and appearance. Wayang is able to present pearl words, which include education, knowledge, awareness, and entertainment. His aesthetic painting is able to present his poetic imagination. 
According to Kayam, art is an element that supports culture [1]. It develops according to the conditions of that culture. Indonesian culture is composed of various regions that develop according to their own history. The experience and capability of the region provide answers to every challenge in terms of giving shape, i.e. the shape of the culture.

Regional Regulation No. 7 of 1996 is on the Preservation, Development and Development of the Regional Cultural Arts of West Java. In Chapter 1, item g, the contents are sincere: "[C]onservation is the effort of digging, preserving, protecting the existence of regional art as cultural richness." Then in Chapter II of Article 3, point a, it states: "The scope of preservation, fostering, and development of regional cultural arts including excavation, research, processing, and maintenance of cultural arts that are considered extinct or rare in particular have characteristics typical of the region" [2].

Cirebon life Wayang art decades of this experience extinction, but according to Sudjana, it has been re-enacted, though not completely.

Art is a form of human expression associated with the social relations of its people, the beliefs and social relations of its people, and has the weight of artistry. Performance art, especially dance, is an idea through a harmonious rhythm, supported by certain elements, has a "theme," and contains a message to be conveyed. Dance is the experience of human life expressed through the medium of human body movement in its reaction to the natural surroundings, essentially distilled art material into works of art to be performed [3]. If emotions, imagination, thoughts, and skills are expressed in motion by dancers, then comes the art s dance is dance.

Puppet theater performances basically use the traditional elements including drama (story-dialog-back sound) and dance and present various symbols and characteristics of certain figures. Significant symbols or symbols can contain various reactions [4]. A symbol is one and solid; it not only conveys meaning to be understood, but rather the "message" to be impregnated. In contrast to people's "meaning," which can only be understood or not understood, the "message" of people can be touched deeply and intensively.

Performance studies or studies show is a new discipline, an interdisciplinary approach that brings a variety of disciplines, including the study of theater, anthropology, anthropology of dance, ethnomusicology, folklore, semiotics, history, linguistics, choreography, and literary criticism [5]. Performing arts in Indonesia come from a different ethnic environment with each other a collective agreement that is hereditary.

According to Sedyawati, performing arts that originated from ethnic neighborhoods were mostly developed in cities [6]. The common characteristics of the arts include, 
among others, the existence of a fixed place to perform art, a system of service rewards in the form of money for artists who perform art, the basis of the agreement "price" as a foundation for artistic performance, and the tendency to specialize in choosing the field of activity. So the arts tend to be pursued as a profession. The development of art in cities is also very influential on the development of art itself, because the art will be adjusted by the entry of modernization into various aspects of its devotees.

The description of the concept mentioned above will be used to explain the position and survival of traditional performing arts in the ethnic areas of the culture of the community.

Education in Indonesia is considered to be not characterized and has not been able to give birth to high-quality citizens, either high learning achievers or well behaved. This can be seen from the wide spread of bad attitude toward life, the violence that often occurs, the deviation from the norm by students, and the reduced attitude of noble courage.

A person who has a strong character has a balanced ability between mind and feeling, emotionality and intellect. In this relationship support factors are needed that should not be forgotten, including physical health. This means that the supporting factors that are often ignored should be given a place, so there is a balance between them. Only in a healthy body will a healthy mind be contained.

The problems that have occurred in the north coast region III of Cirebon are because the value of character education is not inculcated early, and the mindset tendency toward anarchist radicalism has become commonplace and causes damage to the moral, character, and values of life.

The answer to why some people tend to be anarchist, to demonstrate outside the prevailing rules, especially the various forms of violence, even murder, is because they lack intellect, have no stand, no nature oftheir own, and so are easily influenced by others.

In literary studies the term known is characterization, karakerology, characterization, and characterization, how a character or author or director describes the character traits in a story.

Ratna describes characterization through three characteristics, namely physiological, sociological, and psychological [7]. Therefore characterization is considered one of the most important elements, in addition to plot and style of language. In other words, the story becomes interesting when the author succeeds in deeply expressing the inner conflicts of characters, story (plot), the presentation through the medium 
of language, and the presentation through certain techniques and compositions as a whole.

In relation to the values in the development of cultural education and the character of the nation that began to be applied by the National Education Department starting from the 2011 academic year, literary learning is considered important because it can help character formation [8]. In the value of literary learning there are two demands that can be expressed in connection with the formation of this character. First, literary literacy learning should be able to foster a sharper feeling. Someone who has studied many literary works usually has a more sensitive ability to point out what is valuable and what is worthless. The second demand, that literary learning should be able to provide assistance in an effort mengembagkan various qualities of student personality, including persistence, intelligence, pengimajian, and creation.

Literature should not be grouped into aspects of language skills because it is not a similar field. Nevertheless, literary learning is conducted in an integrated manner with language learning either with writing, reading, listening, or speaking skills. In practice, literary teaching includes the development of literary writing skills, literature reading, literary listening, and literary talk.

Based on the above, literary learning includes the following:

1. Writing literature: writing poetry, writing short stories, writing novels, writing dramas

2. Reading literature: reading literature and understanding its meaning, both of literary works in the form of poetry or prose, and drama script

3. Listening to literature: listening to and reflecting on poetry reading, fairy tales, short stories, novels, staging drama

4. Speaking about literature: reciprocating pantuns, reciting, storytelling, role playing, based on manuscripts, retelling the contents of literary works, responding orally to the staging of literary works

With the above-mentioned phenomenon the authors assume that Cirebon is rich in cultural treasures, and in particular the traditions and wayang wong art need to be preserved and the values of local wisdom to the community, learners, government, and observers of the arts and education environment maintained. So the values of existence and diversity budaya Cirebon become sacred and shield local wisdom in West Java. 
This study has the following objectives: 1) To discover how far the people of the Pantura Cirebon region will go to instill cultural values of wayang wong preservation; 2) To determine the role and the function of the pantura community that has been almost extinct, but still preserves the values of local cultural wisdom that exist in the community; 3) To determine the extent of the nation's generation is the younger generation that would later pass on cultural values as the embodiment of local wisdom (local wisdom) that can become a repertoire of wayang wong cultural inheritance in the future; 4) To find out the Kebudayan and multicultural traditions of the pantura community of the Cirebon region of West Java, which is thick with customary traditional values and the attitude of upholding the peculiarities and kultulalismenya. So mindseet and mindset needs to be changed in order to instill character values would love wayang wong tradition in region III Cirebon northern coast of West Java Province.

\section{Methods}

Wayang performance is like a religious ceremony for the worship of ancestors for the believers of "Hyang," which is the indigenous Indonesian culture, and is then developed to be used as a medium of social communication that can be useful for the development of the supporting community. A wayang puppet play is a depiction of human nature and character in a world that reflects the character of man in a peculiar way, so that many are superseded by the appearance of the characters. So there was a shift in function as a medium for the spread of religion, educational means, and teachings of Javanese philosophy. Today the functional shift is becoming more apparent in that it only serves as an entertainment.

Puppetry is a medium that can reflect all aspects of human life (Momot Kamot). Human thought, whether related to ideology, politics, economy, society, culture, or law and the defense of security, can be contained in wayang. Wayang, through the sophistication of the puppeteer, can "discuss" the actual problems in society. Conventionally served ideological systems are reaching a state of gemah ripah loh jinawi toto tentrem kerto raharjo; the social structure of the royal system (king, priest, commander, soldier, etc.); good-bad symbols, main-nasty, praiseworthy; virtue overcomes defeat; religious/religious systems, and others. In addition, problems of human daily life are actually peeled in a somewhat relaxed scene (Limbukan and celestial). 
Many things can be obtained from literature. Haryadi introduces the term "pancaguna" to explain the benefits of old literature, namely (1) to strengthen religious education and character, (2) to increase the love of the homeland, (3) to understand the sacrifice of national heroes, (4) history, (5) introspection and entertainment [9]. Haryadi suggests nine benefits that can be derived from the old literature, namely: (1) it can perperan as entertainment and educational media; (2) its contents can foster the love and pride of the nation and respect for ancestors; (3) its content can broaden the horizons about the beliefs, customs and civilization of the nation; (4) its performance can foster a sense of unity; (5) the process of its creation fosters a creative, responsive, and dynamic soul; (6) it is a source of inspiration for the creation of other art forms; (7) its creation is an example of a diligent, professional, and humble way of working; (8) its performance exemplifies a compact and harmonious relationship; (9) the foreign influences in it provide an overview of the broad social order and worldview [9].

This shows that literature is highly relevant to character education. Literary works are loaded with values of moral education as desired in character education. Wayang Story Wong Cirebon contains educational values about humanity, and education on self-esteem, critical attitude, and social protest.

This study used a qualitative approach to illustrate and describe the musical breech in wayang wong purwa, as expressed by Sukmadinata: "The qualitative research (Qualitative research) is a study aimed at describing and analyzing the phenomenon, events, social activities, attitudes, beliefs, perceptions, and thoughts of individuals and groups. Some descriptions are used to find the principles and explanations that lead to the conclusion" [10].

Based on the qualitative approach, the main instrument is the researcher himself as Nasution (in Prastowo) discloses: "Researchers themselves are the main instruments that go into the field and try to collect information through observation or interview" [11]. In this activity the researchers collect their own information that later in the analysis is described with the aim of obtaining data in the form of phenomena that occur, thoughts, or perceptions of wayang wong. Then, after the data have been collected, the researchers concluded the data so that Become a new thought to the object being studied.

A population is a generalized region consisting of objects/subjects that have certain qualities and characteristics set by researchers to be studied and then conclusions drawn [12].

"Art research limits the scope of its research to intraesthetic factors, which encompass ideas, techniques and media, and artistic expression embodied in works of 
art; and extraesthetic factors, which include behavior, socioculture, the environment that is the context of the presence of the relevant artwork" [13].

The association with the quotation is that researchers collect relevant data on the object under investigation, and then collect data with several data collection techniques such as literature studies, interviews, and documentation studies.

The data obtained by researchers are data that occur in the field of natural observation with existing data sources and true existence in accordance with the objective.

Data obtained by researchers regarding the Wayang Puppet Show of the Cirebon people in Cirebon, Cirebon, and Indramayu are very complex.

\section{Results}

From the data available in the field, the researcher tries to present the data, the character role of the community of the area of III Pantura Cirebon, through the wayang wong show, which is used as the role model of the wayang wong culture, which is now experiencing suspended animation in Cirebon.

The story and the performance of Wayang Cirebon Wayang Arts

\section{"Banner's History as the Cirebon Mask Dance Basics"}

If viewed in his old form, performances of mask dance at the time of his birth acted as a means of religious ritual. And the show took place in a royal environment. On progress, this show has the following functions in the Table 1:

TABle 1: Cirebon Puppet Show Functions.

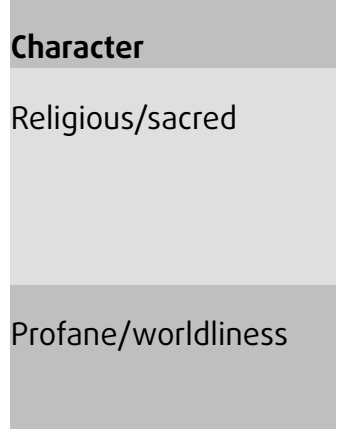

Function
As a symbol of the representation
of community
Art of entertainment because of
aesthetics, visual strength,
dynamics of music and motion

\section{Type}

1. Communal, village celebration for the sake of the nation 2. Bebarang, the initiative of the artist to perform, generally during the famine (dry season) Individual, celebration by individual or family, mitoni (seven months), koulan (syukuran)

The content of wayang wong performances basically describes the life cycle of a human being, from a baby to childhood, and adulthood to a period in which a human being has reached a position. The life cycle contains three elements of life in humans, namely marriage, travel or wandering, and battles. Wayang wong still displays five characters, and the five characters are distinguished by the use of five types of wayang wong. 
The story of Panji talks about princes and daughters of four countries, namely Kediri, Kahuripan, Daha, and Singasari; the four countries are led by brothers. Raden Panji rejected the match with Princess Chandra Kirana, daughter of the Daha kingdom, because she already had Anggraini, but Anggraini was killed and Panji wandered by disguising herself as Panji Kelana Edan. In his escape he meets and falls in love with the horse Semirang, which turns out to be the daughter of Chandra Kirana disguised as a man.

Panji is defined as the first, which is derived from the word siji or one in the Java language. The banner depicts a newborn creature to the world, a picture of a helpless baby. It is seen in small dance movements - small and silent. Panji's marriage to Chandra Kirana makes it the fourth unity of the Javanese kingdom and its center in Jenggala or Kahuripan.

The second character is Pamindo, this character who describes the childhood. He is described as Gunung Sari from the Daha kingdom. The Pamindo character in wayang is told as Raden Kuda Panulis, while in other areas of Losari-Cirebon, Pamindo is identified with the Silk Winangon figure.

This dance is in the second position; the second is Mindo in Java language. The dance that comes after Bannerman is referred to as the horizontal dance, representing the four cardinal directions and the four dance universe is a manifestation of the transcendent aspects of the center, and the first chamber is the position occupied by Gunung Sari from the east.

The third character is Rumyang. In the wayang this figure is identified with Sadewa and Somantri. On the mask of Cirebon Rumyang is a third part dance. Rumyang is described as Candra Kirana, a goddess who transforms into a human being, and performs a masking as Panji Semirang and behaves men. Rumyang's characterization is almost the same as that of Panji; both couples are considered as married couples since the world's top. The origin of the word itself comes from ramyang Rumyangramyang, which means getting light (Toto Amsar Suanda, 1989, p. 24). Things began to light or carangcang Tihang in Sundanese means that only half visible. Rumyang is described as a man who has begun to see the light of the life of the world, although he looks hesitant in his movement but tends to make movements that seem to refuse or throw away. The direction of Rumyang's own space is to the north, and in a primordial concept, the universe of the world is divided into two opposite regions, namely EastNorth and West-South. Rumyang describes adolescence; she symbolizes the eldest daughter but has a male-like principle. That is why this dance features male characters even though she is female. 
The motion in this dance reflects the journey and the disguise of Candrakirana, so throughout the dance he never gives up his mask, so his disguise is successful.

The fourth character is Patih, who always moves in the outside area. He is identified as the King of Soca Windu, the enemy of the Panji family, whereas in wayang he is considered as Raden Setiaki and Gatot Kaca. This dance depicts Tumenggung Magang fighting in the kingdom, the prospective son-in-law of King Bawarna, who seeks to conquer the Antarctic Jingga. In this dance is also found the element of dialogue, so this dance looks like a dance fragment fragments. The figure of Patih is described as symbol maturity date. It is in the South-West or an outsider, worldly, enemy, death, abusive, and malevolent.

The fifth character is Klana; in the wayang story he is identified with Ravana or Dasamuka. Klana or Kelana portrayed a character full of dynamics with physical and worldly desires. Sometimes he is called Menak Jingga because this symbolizes the human unrestrained lust. The figure of Klana depicts a mighty king named Kelana Budanegara, who is infatuated with the daughter of Dewi Tunjung Ayu. Another story mentions that Kelana is the King of Blambangan who wants to marry Dewi Sekartaji from the kingdom of Jenggala, who is none other than Candra Kirana, the Panji couple. If the five masked characters are placed in a cosmological pattern, then the placement, position, and direction of the five characters are as follows in the Table 2:

TABle 2: Cirebon Puppet Dance Concept.

\begin{tabular}{l|c|c|} 
Directions & Character & Character \\
Center & Banner & $\begin{array}{c}\text { Male-female, world surge (the world's } \\
\text { upper-lower world) }\end{array}$ \\
North & Rumyang & Female Candrakirana is male \\
\hline South & Klana & Country man \\
\hline West & Patih & The world's kings \\
\hline East & Pamindo & Male juice is female
\end{tabular}

With the stories or plays above, as a means of learning the importance of culture in local wisdom. Some are learned as learning for the younger generation, students, observers of the arts, and education, that in the nature of our shared culture, these values become experiences that make the mirror of life.

Literacy learning through Wayang wong, students of MA Ash Shiddiqiyyah Cirebon Regency Class XII IPA and IPS Program, based on the following Table 3.

From the data above it may be concluded that level gold students are more dominant at $70 \%$, with discontented students at $15 \%$, and hesitating students also at $15 \%$. It is 
TABLE 3: Students Attitudes toward Literature Learning of Cirebon Puppet.

\begin{tabular}{l|l|l|}
\hline Questions & $\begin{array}{c}\text { Alternative } \\
\text { Answer }\end{array}$ & F \\
\hline $\begin{array}{l}\text { Are you happy to carry out the } \\
\text { literary literature learning of Cirebon } \\
\text { People Puppet a? }\end{array}$ & a. Happy & 70 \\
\hline & b. Not Happy & 15 \\
\hline c. Hesitate & 15 \\
\hline
\end{tabular}

clear that the students are very interested in learning about the literary area of Cirebon puppets.

Students are expected to follow the literary arts literature literature learning, then practice with the values of life in the present, the essence of life bdan life as the foundation of the values of character that must be invested in the life of the society, nation, and state.

The results of the study at Ash Siddiqiyyah Kaliwadas Sumber Cirebon in Class X, interested in and enthusiastic about Cirebon wayang wong art as an effort to preserve the culture.

\section{Conclusion}

The art of puppet show performance is a form of historical evidence where the development of cultural traditions is maintained. The shift of art seems to be extinct, but the effort to preserve the existence of wayang wong with the art of performances inspires a sense of love for our shared culture. Broadly speaking, wayang wong Cirebon is a cultural tradition passed down through generations and creates the icon of cultural development of local wisdom. Nevertheless, young people, teenagers, and the community of Region III Pantura Cirebon continue to preserve and publish through cultural carnival activities the art of wayang puppets in national kanca even not close the possibility at the international level, because with this community will be lovers, connoisseurs, and at the same time protection of this art. Local government through the Department of Culture and Tourism is able to support and inventory wayang wong Cirebon, and remove image and development through activities and designs in the budget for priority art, so thatwayang wong art makes cultural assets. The government and society certainly do not remain silent, instilling in the generation and society that they should work hand-in-hand in the movement and preservation of wayang wong Cirebon. The performance art of wayang wong puppet performance staged through 
cultural carnival activities, seminars, and so on can instill character values and character education among students, society, and academia.

\section{Acknowledgement}

Thus the other can convey about the result of research contained in this article. On this occasion the authors would like to express the appreciation and gratitude to BUDIDN and LPDP as sponsors and all the parties that has big impact to the success and compilation of this research.

\section{Conflict of Interest}

Authors declare that there is no conflict of interest in this research.

\section{References}

[1] Kayam U: Seni, Tradisi, Masyarakat. Jakarta: Sinar Harapan. 1981.

[2] Governor of West Java: Regional Regulation No. 7 on the Preservation and Development of Regional Cultural Arts of West Java. 1996.

[3] Martin JG, Franklin CW: Minority Group Relations. Ohio: Charles E Merrill Publishing Company. 1973.

[4] Hadi YS: Kajian Tari Teks dan Konteks. Yogyakarta: Pustaka Book Publisher. 2007.

[5] Schechner R: Performance Studies: An Introduction. London: Routledge. 2002.

[6] Sedyawati E: Pertumbuhan Seni Pertunjukan. Jakarta: Sinar Harapan. 1981.

[7] Ratna NK: Peranan Karya Sastra, Seni, dan Budaya dalam Pendidikan Karakter. Yogyakarta: Pustaka Pelajar. 2014.

[8] Ministry of National Education: Pengembangan Budaya dan Karakter Bangsa. Jakarta: Research and Curriculum Development Center. 2010.

[9] Haryadi: Sastra Melayu. Yogyakarta: IKIP Yogyakarta. 1994.

[10] Sukmadianta NS: Metode Penelitian Pendidikan. Bandung: PT Remaja Rosada Кагуа. 2012.

[11] Prastowo A: Menguasai Teknik-teknik Koleksi Data Penelitian Kualitatif. Yogyakarta: DIVA Press. 2010.

[12] Sugiyono: Metode Penelitian Kuantitatif, Kualitatif, dan R\&D. Bandung: ALfabeta. 2013. 
[13] Rohidi TR: Pendidikan Seni: Isu dan Paradigma. Semarang: PT Prima Cipta Nusantara. 2014. 